\title{
Body composition and metabolic profile in adults with vitamin $D$ deficiency
}

\section{Composição corporal e perfil metabólico na deficiência de vitamina $D$ sérica em adultos}

\section{A B S T R A C T}

\section{Objective}

To investigate the body composition and metabolic profile in individuals in terms of different concentrations of serum vitamin $D$, ranging from deficiency to sufficiency.

\section{Methods}

A cross-sectional study of 106 adults of both genders, who were divided into three groups according to vitamin D levels: deficiency: $<20 \mathrm{ng} / \mathrm{mL}$; insufficiency: $20-29.9 \mathrm{ng} / \mathrm{mL}$; and sufficiency: 30-100 $\mathrm{ng} / \mathrm{mL}$. Anthropometric evaluation included weight, height, and body circumferences. Fat mass and lean mass were assessed using the Tetrapolar bioelectrical impedance method. Clinical and biochemical evaluations were also carried out. Insulin resistance was estimated using the Homeostasis Model Assessment Insulin index.

\section{Results}

The analysis showed that the main alterations in individuals in the vitamin D deficiency group were higher triglycerides, very low density lipoprotein - cholesterol, fasting blood glucose, insulin, glycated hemoglobin, body mass index, body fat percentage, lean mass percentage, waist circumference, and Homeostasis Model Assessment Insulin than those of the vitamin D sufficient group $(p<0.05)$.

1 Universidade Estadual de Campinas, Faculdade de Ciências Médicas, Departamento de Clínica Médica. R. Tessália Vieira de Camargo, 126, Cidade Universitária, 13083-887, Campinas, SP, Brasil. Correspondência para/Correspondence to: LM ROCHA. E-mail: <liane_mr@yahoo.com.br>

2 Universidade Estadual de Campinas, Faculdade de Ciências Médicas, Departamento de Cirurgia. Campinas, SP, Brasil. Article based on the doctoral dissertation of LM ROCHA, intitled: "Relação entre padrões de sono, concentrações de vitamina D, obesidade e resistência à insulina”. Universidade Estadual de Campinas; 2016.

Support: Fundo de Apoio ao Ensino, à Pesquisa e Extensão (Fundação de Desenvolvimento da Universidade Estadual de Campinas, $\left.n^{\circ} 519.294\right)$. 


\section{Conclusion}

It was found that vitamin D deficiency causes important body composition and metabolic changes, which may lead to diseases such as diabetes Mellitus and metabolic syndrome.

Keywords: Body composition. Obsesity. Vitamin D.

\section{R E S U M O}

\section{Objetivo}

Investigar a composição corporal e o perfil metabólico de indivíduos com diferentes concentrações de vitamina D sérica, da deficiência à normalidade.

\section{Métodos}

Estudo transversal realizado com 106 indivíduos adultos, de ambos os sexos, divididos em três grupos de acordo com as concentrações de vitamina D: deficiência: <20ng/mL; insuficiência: 20-29,9ng/mL e suficiência: 30-100ng/mL. A avaliação antropométrica incluiu peso, altura e circunferências. Massa gorda e massa magra foram avaliadas pelo teste de bioimpedância tetrapolar. Também foram realizadas avaliação clínica e bioquímica. A resistência à insulina foi calculada pelo índice Homeostasis Model Assessment Insulin.

\section{Resultados}

A análise apontou que as principais alterações dos indivíduos com deficiência de vitamina $D$ foram valores elevados de triglicérides, lipoproteína de muito baixa densidade - colesterol, glicemia de jejum, insulina, hemoglobina glicada, indice de massa corporal, porcentagem de gordura corporal, porcentagem de massa magra, circunferência da cintura e Homeostasis Model Assessment Insulin quando comparados ao grupo Suficiência vitamina $D(p<0,05)$.

\section{Conclusão}

Observou-se que na deficiência da vitamina D ocorrem importantes alterações tanto no metabolismo como na composição corporal, essas alterações podem contribuir para o surgimento de doenças como diabetes Mellitus e síndrome metabólica.

Palavras-chave: Composição corporal. Obesidade. Vitamina D.

\section{INTRODUCTION}

It is known that sunlight provides most humans with their vitamin $\mathrm{D}$ requirement by synthesis in the skin (80-90\%) [1]. However, although there is abundance of sunlight in many countries, vitamin D deficiency is currently a highly prevalent condition, and it has been considered a public health problem that can affect more than $90 \%$ of individuals depending on the population studied [2].

There are several factors that affect cutaneous production of vitamin $D$, such as winter time, long distance from the equator [3], high levels of melanin, and aging [4]. The considerable changes that have occurred in lifestyle habits over the last decades can also influence vitamin D synthesis. Among them is the low exposure to sunlight or exposure when there is lower radiation intensity level [5].

For some time, scientists have believed that vitamin $\mathrm{D}$ played a critical role only in bone mineral metabolism, especially calcium. However, vitamin D is currently considered a true steroid hormone, and due to its significant influence on metabolism and cell proliferation [6], vitamin D deficiency has been associated with several diseases such as obesity and diabetes [7-10].

In addition, vitamin D may also be associated with body composition, as some studies have shown an inverse association between 25-Hydroxyvitamin D (25OHD) concentration and percentage of body fat $[11,12]$. However, McGill et al. [13] did not find this association. These 
authors found an inverse association of vitamin $\mathrm{D}_{3}$ with and body weight, Body Mass Index (BMI), and waist circumference. Disagreement among results has also been found in studies on metabolic syndrome components. Some studies have reported an inverse association between $25 \mathrm{OHD}$ and a number of metabolic syndrome components [14], whereas others did not find the same results $[15,16]$.

Considering the major role of vitamin D in human metabolic processes and its association with body composition, this study aimed to evaluate the biochemical and anthropometric characteristics of individuals in terms of vitamin D deficiency and sufficiency, in order to identify metabolic alterations that may result from its deficiency.

\section{METHOD S}

Convenience sampling was used resulting in a sample of 116 individuals of both genders, from the city of Campinas (SP) (latitude 22 degrees South), aged 18-60 years, with different phenotypes: (well-nourished, obese class I, II, and III), normoglycemic, or insulin resistant. It is worth mentioning that there were no underweight and overweight participants. Only subjects with normal values of urea, creatinine, alanine aminotransferase, aspartate aminotransferase, and gamma glutamyl transferase were included, indicating normal kidney and liver function, which is important in vitamin D metabolism.

Subjects who regularly used oral antihypertensive, hypoglycemic, and lipidlowering drugs were also included in the sample. The main exclusion criteria were: use of vitamin $D$ and calcium supplements, insulin use, renal disease, liver disease, hypothyroidism, cancer, and pregnancy or lactation. Finally, it is important to mention that all volunteer participants were informed about the procedures to be performed and signed the Informed Consent Form to participate in this study, which was approved by the Research Ethics Committee of the
Universidade Estadual de Campinas (CEP n ${ }^{\circ}$ 483.905; CAAE 218443135.5404).

A cross-sectional study was carried out, in which, based on a volunteer application form, 116 individuals who met the inclusion/ exclusion criteria were included. After the tests, 10 subjects were excluded due to unknown changes, such as hypothyroidism and elevated creatinine levels or liver enzymes. Therefore, the final sample was composed of 106 individuals.

The assessments were carried out on the same day by trained healthcare professionals, and included clinical evaluation (blood pressure), anthropometric evaluation (weight, height, waist circumference, and percentage of body fat), and biochemical profile evaluation - blood glucose, insulin, glycated Hemoglobin (HbA1c), total cholesterol and cholesterol fractions, triglycerides, fraction of 250HD, Parathyroid Hormone (PTH), total and ionized calcium and phosphorus levels, and C-Reactive Protein (CRP). Socioeconomic data (income and level of education) and lifestyle habits were also collected (smoking, alcohol consumption, physical activity, and use of sunscreen). Finally, the participants were divided into three groups according to $250 H D$ serum levels: deficiency: $<20 \mathrm{ng} / \mathrm{mL}$; insufficiency: 20-29.9ng/mL; and sufficiency: 30-100ng/mL [17].

Blood pressure was measured following the recommendations of the Brazilian Society of Cardiology [18] using a mercury column sphygmomanometer (Model 980, OFTEC ${ }^{\circledR}$, São Paulo, SP, Brazil). Anthropometric measurements included weight, height, $\mathrm{BMI}$, and waist circumference. Weight was measured in kilograms using a previously calibrated precision mechanical scale (Model W110H, Welmy ${ }^{\circledR}$, São Paulo, SP, Brazil). Height was assessed to the nearest $0.1 \mathrm{~cm}$ using a stadiometer. Participants were measured and weighed without shoes and wearing light clothes. After data collection, the BMI was calculated and used for the classification of nutritional status [19]. Waist circumference was measured with the individuals standing up 
straight, relaxing the diaphragm and with the weight distributed evenly to both feet [20]. A flexible non-elastic tape measure was used, and the measurements were performed over the umbilical scar [21]. Body composition was assessed using the bioelectrical impedance analysis (Model BIA 310, Biodynamics ${ }^{\circledR}$, Seattle, Washington, United States). Measurements were taken before or after the menstrual period and after subjects had fasted for 12 hours and had an empty bladder, according to the fasting time used in the biochemical assessments. Moreover, subjects were also instructed to not perform physical exercises and to not consume alcoholic beverages the day before the evaluation.

Blood samples were collected after 12 hours of fasting. The samples were kept in a freezer at $-20^{\circ} \mathrm{C}$. Enzymatic colorimetric methods (Roche Diagnostics, Mannheim, Germany) with commercial kits were used to analyze total cholesterol (serum/cholesterol oxidase-peroxidase antiperoxidase), triglycerides (glycerol phosphate oxidase-peroxidase antiperoxidase), glucose (gluco-quant glucose/hexokinase), and total calcium. Glycated hemoglobin was analyzed by liquid chromatography (high-performance liquid chromatography) (BioRad Variant II, BioRad Laboratories, Inc., Hercules, United States); serum insulin concentration was measured by chemiluminescence immunoassay (DPD Immulite 2000, Siemens Medical Solutions USA, Inc., Malvern, Pennsylvania, United States); CRP was assessed by ultrasensitive nephelometry (BNII, nephelometer, Dade Behring, Marbung, Germany); PTH was determined using ElectroChemiluminescence Immunoassay (ECLIA, Elecsys 2010, Roche Diagnostics, Mannheim, Germany); serum 250HD concentration was measured by Chemiluminescence Immunoassay (CLIA, DiaSorin Liaison, Stillwater, United States); ionized calcium was determined using the ABL800 Flex benchtop blood gas analyzer (Radiometer Medical ApS, Copenhagen, Denmark); and serum inorganic phosphorus was measured by the enzymatic colorimetric and phosphomolybdate ultraviolet methods (Biosystem, Barcelona, Spain).
Socioeconomic analysis included questions about income and level of education. Among the lifestyle habits evaluated were: smoking (current smoker, non-smoker, and former smoker), alcohol consumption (number of drinks/ month), physical activity (minutes per week: sedentary (0 minute/work) <150 minute/work or $\geq 150$ minute/work engaged in moderate or vigorous physical activities) [22]. The use of sunscreen (yes or no) was also evaluated. This study was carried out from 2013 to 2015 during all seasons of the year. Sun exposure was assessed using a weekly sunlight exposure recall questionnaire considering the exposed skin area [23]. Insulin resistance was assessed by the Homeostasis Model Assessment Insulin (HOMAIR) Index, and it was calculated as [(fasting insulin) $x$ (fasting blood glucose)]/22.5 [24] and using the American Diabetes Association criteria [25]. Individuals with HOMA-IR values $>2.71$ (cut-off value for diagnosing $I R$ in the Brazilian population), were considered insulin resistant [26]. Metabolic syndrome was classified according to the International Diabetes Federation criteria, which has established values for waist circumference $(\geq 94 \mathrm{~cm}$ in males, $\geq 80 \mathrm{~cm}$ in females) and presence of two more factors among the following factors: fasting blood glucose $>100 \mathrm{mg} / \mathrm{dL}$ including diabetes Mellitus, triglycerides $\geq 150 \mathrm{mg} / \mathrm{dL}$ or use of specific treatment for this lipid abnormality, High Density Lipoprotein-cholesterol (HDL-c) $<40 \mathrm{mg} /$ $\mathrm{dL}$ in males and $<50 \mathrm{mg} / \mathrm{dL}$ in females and blood pressure $\geq 130 / 85 \mathrm{mmHg}$ or use of medication to treat hypertension [27].

Statistical analysis was carried out using the GraphPad Prism 7 program (GraphPad Software, California, United States). The results were expressed as mean \pm standard error of the mean, and the number of participants ( $n$ ) was expressed as a total number or percentage. D'Agostino and Pearson test was used to check whether data were normally distributed. Analysis of Variance (ANOVA) followed by the Tukey's test was used when data followed a normal 
distribution, and the Kruskal-Wallis test followed by the Dunn's test was used for the non-normally distributed data. Student's- $t$ test was used to compare two sets of data that followed normal distribution; the Mann-Whitney $U$ test was used for the non-parametric data.

\section{R E S U L T S}

Participants were recruited and evaluated in all seasons of the year; $34.9 \%$ in the summer; $36.8 \%$ in the fall; $8.5 \%$ in the winter, and $19.8 \%$ in spring. The final sample consisted of 106 individuals (76.4\% women); most individuals (64.2\%) had vitamin D deficiency/insufficiency. In the final sample, $35.8 \%$ of the participants were well-nourished, $17.0 \%$ were obese Class I, $14.2 \%$ were obese Class II, and $33.0 \%$ were obese Class III. Most of them had a High School Education, income of 1-5 times the minimum wage, did not smoke, did not consume alcoholic beverages, and were not engaged in physical activities (Table 1). After dividing the groups into categories, the Vitamin D Deficiency group was composed of 15 individuals; the Vitamin D Insufficiency group was composed of 53 individuals; and the Vitamin D Sufficiency group was composed of 38 individuals. The vitamin D categories (Deficiency [D], Insufficiency [I], and Sufficiency [S]) were validated by statistical analysis, which showed different values across all three groups.

The socioeconomic and health profiles and lifestyle habits of the participants did not significantly influence $250 \mathrm{HD}$ concentration. A significant difference in the $250 \mathrm{OHD}$ concentration was observed only in the Vitamin D Deficiency group in terms of use of sunscreen; those who used it had lower 250HD concentrations (Table 2).

As can be seen from Table 3, there was no difference between the groups in terms of age. The major differences were observed between the
Vitamin D Deficiency and Vitamin D Insufficiency groups in terms of body composition; the Vitamin D Deficiency group had higher BMl values, percentage of body fat, percentage of lean mass, and waist circumference.

The participants' metabolic and lipid profiles also showed significant differences. The Vitamin D deficiency group had higher insulin, HbA1c, HOMA-IR, glucose, triglycerides, and Very Low Density Lipoprotein-cholesterol (VLDL-c) levels than those of the Vitamin D Sufficiency group. Although there was no significant difference in the Vitamin D Deficiency group in terms of the presence or absence of metabolic syndrome, this group had a larger number of metabolic

Table1. Participants' socioeconomic and health profiles and lifestyle habits. Campinas (SP), Brazil (2013-2015).

\begin{tabular}{|c|c|c|}
\hline Variables & $\mathrm{n}$ & $\%$ \\
\hline \multicolumn{3}{|l|}{ Gender } \\
\hline Male & 25 & 23.6 \\
\hline \multicolumn{3}{|l|}{ Menopause } \\
\hline Female & 81 & 76.4 \\
\hline Yes & 18 & 22.2 \\
\hline \multicolumn{3}{|l|}{ Level of education } \\
\hline No & 63 & 77.8 \\
\hline Elementary and Middle School & 17 & 16.0 \\
\hline High School & 55 & 51.9 \\
\hline Higher Education & 30 & 28.3 \\
\hline Postgraduate Education & 4 & 3.8 \\
\hline \multicolumn{3}{|l|}{ Income } \\
\hline$<1$ minimum wage & 1 & 0.9 \\
\hline $1-5$ times the minimum wage & 79 & 74.5 \\
\hline $6-10$ times the minimum wage & 21 & 19.8 \\
\hline$>10$ times the minimum wage & 5 & 4.7 \\
\hline \multicolumn{3}{|l|}{ Alcohol consumption } \\
\hline$<1$ drink per month & 68 & 64.2 \\
\hline 1-4 drinks per month & 17 & 16.0 \\
\hline 5-7 drinks per month & 5 & 4.7 \\
\hline >7 drinks per month & 16 & 15.1 \\
\hline \multicolumn{3}{|l|}{ Tabagism } \\
\hline Non-smoker & 90 & 84.9 \\
\hline Current smoker & 11 & 10.4 \\
\hline Former smoker & 5 & 4.7 \\
\hline \multicolumn{3}{|l|}{ Physical activity } \\
\hline Sedentary & 65 & 61.3 \\
\hline$<150$ minutes/work & 18 & 17.0 \\
\hline$\geq 150$ minutes/work & 23 & 21.7 \\
\hline
\end{tabular}


Table 2. Concentration of serum 25-hydroxyvitamin $\mathrm{D}(\mathrm{ng} / \mathrm{mL})$ according to participants' socioeconomic and health profiles and lifestyle categorized as Vitamin D Deficiency (D), Insufficiency (I), and Sufficiency (S) ( $n=$ absolute number in each subpopulation). Campinas (SP), Brazil (2013-2015).

\begin{tabular}{|c|c|c|c|c|c|c|c|c|c|c|}
\hline \multirow{3}{*}{ Variables } & \multicolumn{10}{|c|}{ Vitamin D } \\
\hline & \multicolumn{3}{|c|}{$\begin{array}{l}\text { Deficiency } \\
(<20 \mathrm{ng} / \mathrm{mL})\end{array}$} & \multicolumn{3}{|c|}{$\begin{array}{c}\text { Insufficiency } \\
(20-29.9 n g / m L)\end{array}$} & \multicolumn{3}{|c|}{$\begin{array}{l}\text { Sufficiency } \\
(>30 \mathrm{ng} / \mathrm{mL})\end{array}$} & \multirow[t]{2}{*}{$p$} \\
\hline & M & & SD & M & & SD & M & & SD & \\
\hline Vitamin D (ng/mL) & 17.5 & \pm & 2.75 & 25.1 & \pm & 2.31 & 36.4 & \pm & 5.34 & $<0.0001$ \\
\hline Gender & & & & & \pm & & & & & \\
\hline Male & 18.4 & \pm & 2.07 & 24.9 & \pm & 0.81 & 37.3 & \pm & 4.55 & $D=0.5099$ \\
\hline \multirow[t]{2}{*}{ Female } & 17.3 & \pm & 2.93 & 25.1 & \pm & 0.34 & 36.1 & \pm & 5.64 & $\mathrm{I}=0.8434$ \\
\hline & & & & & & & & & & $S=0.2537$ \\
\hline \multicolumn{11}{|l|}{ Menopause } \\
\hline Yes & 19.4 & \pm & 0.45 & 24.8 & \pm & 1.61 & 34.5 & \pm & 3.40 & $D=0.1455$ \\
\hline \multirow[t]{2}{*}{ No } & 16.6 & \pm & 3.09 & 25.2 & \pm & 2.39 & 36.3 & \pm & 5.86 & $\mathrm{I}=0.5975$ \\
\hline & & & & & & & & & & $S=0.7382$ \\
\hline \multicolumn{11}{|l|}{ Level of education } \\
\hline Elementary and Middle School & 19.1 & \pm & 0.28 & 25.0 & \pm & 2.03 & 34.2 & \pm & 2.41 & $D=0.9665$ \\
\hline High School & 17.6 & \pm & 2.70 & 25.4 & \pm & 2.46 & 37.7 & \pm & 6.24 & $\mathrm{I}=0.2924$ \\
\hline Higher Education & 16.6 & \pm & 3.39 & 24.2 & \pm & 2.21 & 35.1 & \pm & 3.00 & $S=0.3113$ \\
\hline Postgraduate Education & - & & & 26.0 & \pm & 0.71 & 39.9 & \pm & 12.73 & \\
\hline \multicolumn{11}{|l|}{ Income } \\
\hline$<1$ minimum wage & - & & & - & & & 35.01 & & & $D^{*}$ \\
\hline $1-5$ times the minimum wage & 17.34 & \pm & 2.77 & 25.20 & \pm & 2.32 & 36.10 & \pm & 3.77 & $\mathrm{I}=0.7823$ \\
\hline $6-v 10$ times the minimum wage & 19.81 & & & 24.70 & \pm & 2.69 & 37.90 & \pm & 8.43 & $S=0.3559$ \\
\hline$>10$ times the minimum wage & - & & & 24.73 & \pm & 1.33 & 30.91 & & & \\
\hline \multicolumn{11}{|l|}{ Alcohol consumption } \\
\hline$<1$ drink per month & 16.9 & \pm & 3.14 & 25.2 & \pm & 2.37 & 36.1 & \pm & 5.83 & $D=0.2856$ \\
\hline 1-4 drinks per month & 19.5 & & & 24.8 & \pm & 1.94 & 37.3 & \pm & 4.89 & $\mathrm{I}=0.6970$ \\
\hline 5-7 drinks per month & 16.8 & & & 24.4 & \pm & 4.45 & 31.2 & \pm & 0.35 & $S=0.4362$ \\
\hline 7 drinks per month & 19.0 & \pm & 0.98 & 24.4 & \pm & 2.22 & 37.5 & \pm & 4.92 & \\
\hline \multicolumn{11}{|l|}{ Tabagism } \\
\hline Non-smoker & 17.40 & \pm & 2.40 & 24.9 & \pm & 2.25 & 36.7 & \pm & 5.71 & $D=0.8759$ \\
\hline Current smoker & 17.10 & \pm & 4.59 & 26.9 & \pm & 2.15 & 34.4 & \pm & 2.89 & $\mathrm{I}=0.1011$ \\
\hline Former smoker & 19.81 & & & 25.0 & \pm & 3.96 & 35.8 & \pm & 0.07 & $S=0.5457$ \\
\hline \multicolumn{11}{|l|}{ Physical activity } \\
\hline Sedentary & 18.0 & \pm & 2.62 & 24.8 & \pm & 2.09 & 35.8 & \pm & 4.61 & $D=0.8770$ \\
\hline$<150$ minutes/work & 17.1 & \pm & 3.71 & 25.8 & \pm & 2.75 & 37.0 & \pm & 6.61 & $\mathrm{I}=0.5254$ \\
\hline$\geq 150$ minutes/work & 16.1 & \pm & 1.69 & 25.3 & \pm & 2.64 & 37.5 & \pm & 6.62 & $S=0.9474$ \\
\hline \multicolumn{11}{|l|}{ Use of sunscreen } \\
\hline Yes & 15.2 & \pm & 2.44 & 25.1 & \pm & 2.27 & 37.9 & \pm & 6.96 & $D=0.0430^{*}$ \\
\hline \multirow[t]{2}{*}{ No } & 18.3 & \pm & 2.44 & 25.1 & \pm & 2.37 & 35.8 & \pm & 4.54 & $\mathrm{I}=0.9523$ \\
\hline & & & & & & & & & & $S=0.7112$ \\
\hline
\end{tabular}

Note: " $\mathrm{n}<3$ (participants) did not enter into the statistical analysis. Parametric data: Students' $t$-test or Analysis of Variance (ANOVA) followed by Tukey's test. Non-parametric data: Mann Whitney test or Kruskal-Wallis test followed by Dunn's test. M: Mean; SD: Standard Deviation.

syndrome components than the Vitamin D Sufficient group.

The only differences observed in the Vitamin D Insufficiency group were higher levels of glucose and HbA1c than those of the Vitamin D Sufficiency group. No difference was observed between the Vitamin D Deficiency and Insufficiency groups. 
Table 3. Age; body composition; metabolic, cardiovascular, and lipid profile; and calcium and phosphate balance in the participants according to the Vitamin D Deficiency (D), Insufficiency (I), and Sufficiency (S) categories. Campinas (SP), Brazil (2013-2015).

\begin{tabular}{|c|c|c|c|c|c|c|c|c|c|c|}
\hline \multirow{3}{*}{ Variables } & \multicolumn{10}{|c|}{ Vitamin D } \\
\hline & \multicolumn{3}{|c|}{$\begin{array}{l}\text { Deficiency } \\
(<20 \mathrm{ng} / \mathrm{mL})\end{array}$} & \multicolumn{3}{|c|}{$\begin{array}{c}\text { Insufficiency } \\
(21-29.9 \mathrm{ng} / \mathrm{mL})\end{array}$} & \multicolumn{3}{|c|}{$\begin{array}{l}\text { Sufficiency } \\
\text { (>30ng/mL) }\end{array}$} & \multirow[t]{2}{*}{$p$} \\
\hline & M & & SD & M & & SD & M & & SD & \\
\hline Age (years) & 39.30 & \pm & 10.17 & 41.90 & \pm & 11.36 & 37.40 & \pm & 11.36 & 0.1665 \\
\hline \multicolumn{11}{|l|}{ Body Composition } \\
\hline BMI $(\mathrm{kg} / \mathrm{m} 2)$ & 38.98 & \pm & $8.75^{\mathrm{a}}$ & 34.91 & \pm & $10.26^{\mathrm{ab}}$ & 30.64 & \pm & $9.33^{\mathbf{b}}$ & 0.0182 \\
\hline Body fat (\%) & 41.18 & \pm & $6.67^{\mathrm{a}}$ & 36.54 & \pm & $11.76^{\mathrm{ab}}$ & 32.12 & \pm & $9.88^{b}$ & 0.0153 \\
\hline Lean mass (\%) & 61.35 & \pm & $13.12^{\mathrm{a}}$ & 56.49 & \pm & $14.87^{\mathrm{ab}}$ & 54.39 & \pm & $11.96^{\mathbf{b}}$ & 0.0153 \\
\hline Waist circumference (cm) & 119.93 & \pm & $19.96^{\mathrm{a}}$ & 110.29 & \pm & $24.48^{\mathrm{ab}}$ & 100.43 & \pm & $21.13^{b}$ & 0.0142 \\
\hline \multicolumn{11}{|l|}{ Metabolic profile } \\
\hline Blood glucose (mg/dL) & 99.80 & \pm & $25.61^{a}$ & 99.11 & \pm & $31.82^{\mathrm{a}}$ & 83.87 & \pm & $13.89^{b}$ & 0.0280 \\
\hline Insulin (uUI/mL) & 20.74 & \pm & $11.43^{\mathrm{a}}$ & 13.73 & \pm & $8.54^{\mathrm{ab}}$ & 10.93 & \pm & $7.26^{\mathbf{b}}$ & 0.0097 \\
\hline \multicolumn{11}{|l|}{ Glucose tolerance (ADA) } \\
\hline Normal & 17.10 & \pm & 3.12 & 25.10 & \pm & 2.02 & 36.60 & \pm & 5.33 & $D=0.7745$ \\
\hline Prediabetes & 18.30 & \pm & 2.12 & 23.05 & \pm & 1.65 & 36.20 & \pm & 1.00 & $\mathrm{I}=0.1630$ \\
\hline Diabetes & 17.60 & \pm & 2.92 & 25.48 & \pm & 2.74 & 35.50 & \pm & 6.26 & $S=0.3537$ \\
\hline \multicolumn{11}{|l|}{ Metabolic Syndrome (IDF) } \\
\hline Yes & 18.30 & \pm & 2.46 & 25.00 & \pm & 2.57 & 36.30 & \pm & 6.00 & $D=0.0861$ \\
\hline No & 14.90 & \pm & 3.00 & 25.00 & \pm & 2.09 & 36.40 & \pm & 5.17 & $\begin{array}{l}\mathrm{I}=0.9014 \\
\mathrm{~S}=0.6639\end{array}$ \\
\hline Number of MS components & 3.14 & \pm & $1.23^{\mathrm{a}}$ & 2.51 & \pm & $1.49^{\mathrm{ab}}$ & 1.74 & \pm & $1.41^{\mathrm{b}}$ & 0.0040 \\
\hline HOMA-IR & 5.08 & \pm & $2.70^{\mathrm{a}}$ & 3.56 & \pm & $2.66^{\mathrm{ab}}$ & 2.34 & \pm & $1.74^{b}$ & 0.0055 \\
\hline $\mathrm{HbA} 1 \mathrm{c}(\%)$ & 6.03 & \pm & $0.97^{\mathrm{a}}$ & 5.89 & \pm & $1.02^{\mathrm{a}}$ & 5.35 & \pm & $0.57^{\mathbf{b}}$ & 0.0348 \\
\hline PCR (mg/dL) & 0.55 & \pm & $0.43^{\mathrm{a}}$ & 0.70 & \pm & $0.92^{\mathrm{a}}$ & 0.56 & \pm & $0.63^{\mathrm{a}}$ & 0.6407 \\
\hline \multicolumn{11}{|l|}{ Cardiovascular profile } \\
\hline $\mathrm{SBP}(\mathrm{mmHg})$ & 122.78 & \pm & $7.87^{\mathrm{a}}$ & 124.30 & \pm & $12.25^{\mathrm{a}}$ & 123.29 & \pm & $20.00^{a}$ & 0.4687 \\
\hline $\mathrm{DBP}(\mathrm{mmHg})$ & 84.11 & \pm & $7.79^{\mathrm{a}}$ & 82.13 & \pm & $10.73^{a}$ & 81.68 & \pm & $13.42^{\mathrm{a}}$ & 0.5992 \\
\hline \multicolumn{11}{|l|}{ Lipid profile } \\
\hline Total Cholesterol (mg/dL) & 193.07 & \pm & $49.66^{a}$ & 182.53 & \pm & $33.81^{\mathrm{a}}$ & 177.05 & \pm & $34.11^{\mathrm{a}}$ & 0.5070 \\
\hline $\mathrm{HDL}-\mathrm{C}(\mathrm{mg} / \mathrm{dL})$ & 45.00 & \pm & $9.79^{a}$ & 48.38 & \pm & $11.62^{\mathrm{a}}$ & 52.78 & \pm & $12.53^{\mathrm{a}}$ & 0.0656 \\
\hline LDL-C (mg/dL) & 118.71 & \pm & $41.24^{a}$ & 108.51 & \pm & $32.06^{\mathrm{a}}$ & 104.95 & \pm & $28.51^{\mathrm{a}}$ & 0.3987 \\
\hline VLDL (mg/dL) & 30.38 & \pm & $17.07^{\mathrm{a}}$ & 25.47 & \pm & $14.52^{\mathrm{ab}}$ & 19.35 & \pm & $9.44^{b}$ & 0.0307 \\
\hline Triglycerides (mg/dL) & 170.29 & \pm & $107.71^{\mathrm{a}}$ & 127.08 & \pm & $72.65^{\mathrm{ab}}$ & 96.73 & \pm & $47.06^{b}$ & 0.0213 \\
\hline \multicolumn{11}{|l|}{ Calcium and phosphate balance } \\
\hline Total calcium (mg/dL) & 9.47 & \pm & $0.31^{\mathrm{a}}$ & 9.41 & \pm & $0.34^{\mathrm{a}}$ & 9.34 & \pm & $0.32^{\mathrm{a}}$ & 0.4003 \\
\hline Ionized calcium (mmol/L) & 1.19 & \pm & $0.020^{\mathrm{a}}$ & 1.19 & \pm & $0.038^{\mathrm{a}}$ & 1.18 & \pm & $0.03^{a}$ & 0.3275 \\
\hline Phosphorous (mg/dL) & 3.14 & \pm & $1.23^{\mathrm{a}}$ & 2.51 & \pm & $1.49^{b}$ & 1.74 & \pm & $1.41^{\mathrm{a}}$ & 0.0513 \\
\hline Parathyroid hormone $(\mathrm{pg} / \mathrm{mL})$ & 61.66 & \pm & $23.42^{\mathrm{a}}$ & 47.27 & \pm & $14.02^{\mathrm{ab}}$ & 48.60 & \pm & $21.65^{b}$ & 0.0342 \\
\hline Weekly sunlight exposure & 13.80 & \pm & $10.76^{\mathrm{a}}$ & 19.75 & \pm & $11.08^{\mathrm{ab}}$ & 21.63 & \pm & $11.50^{\mathbf{b}}$ & 0.0328 \\
\hline
\end{tabular}

Note: Values followed by the same letter are not significantly different according to the Tukey's or Dunn's tests.

ADA: American Diabetes Asssociation; HbA1c: Glycated Hemoglobin; PCR: C-Reactive Protein; SBP: Systolic Blood Pressure; DBP: Diastolic Blood Pressure; MS: Metabolic Syndrome; BMI: Body Mass Index.

As for the calcium and phosphate balance, despite the significant differences in 250HD concentrations, no differences were observed between total and ionized serum calcium concentrations across the three groups. The Vitamin D Deficiency group had higher PTH levels and lower sunlight exposure than the Vitamin D Sufficiency group. 


\section{I SCUSSIO N}

The objective of this study was to evaluate the biochemical and anthropometric characteristics of individuals in terms of vitamin $D$ deficiency and sufficiency to identify metabolic alterations that may occur due to vitamin deficiency. It was found that the increase in the prevalence of vitamin $D$ deficiency is alarming due to its important role in the metabolism and its effect on body composition.

It was also observed that the Vitamin D Deficiency group had more metabolic alterations than Insufficiency and Sufficiency groups. The main changes in Vitamin D Deficiency group were: (a) higher levels of triglyceride, VLDL-C, insulin, glucose, $\mathrm{HbA1C}, \mathrm{BMl}$, percentage of body fat, percentage of lean mass, waist circumference, HOMA-IR; (b) number of altered metabolic syndrome components, and (c) lower sunlight exposure than those of the Vitamin D Sufficiency group. Data analysis showed that the socioeconomic and health characteristics and the lifestyle habits of participants did not significantly influence the $250 \mathrm{HD}$ concentration.

These results demonstrate that body composition, metabolic profile, and lipid profile influence or are influenced by the $250 \mathrm{HD}$ serum concentration. Therefore, the number of metabolic syndrome components was larger in the Vitamin D Deficiency group. On the other hand, the calcium values did not differ across the 3 groups, even in the Vitamin D Deficiency group, and high PTH levels were found in the Vitamin D Deficiency group, indicating an inability to activate the vitamin $\mathrm{D}$.

In the Vitamin D Insufficiency group, the fasting blood glucose levels, and, consequently, the HbA1c levels were higher than those in the Vitamin D Sufficiency group. PTH and insulin levels were lower in this group than in the Vitamin D Deficiency group. However, these data suggest the onset of insulin resistance, already established in the Vitamin D Deficiency group.
Studies including different populations [28-30] found that vitamin D exerted a protective effect against insulin resistance. Some possible reasons include: (a) the presence of Vitamin $D$ Receptors (VDRs) in $\beta$-cells and vitamin D-dependent calcium binding proteins in the pancreas [31]; (b) conversion of vitamin D into its active form, which can occur in $\beta$-cells, by the 1-alpha-hydroxylase enzyme [32]; (c) stimulation of expression of insulin receptor by vitamin D, increasing glucose transport response to insulin [33]; (d) the role of vitamin D in maintaining normal calcium influx since insulin secretion is a calcium dependent process; and finally (e) activation of human insulin gene transcription, which has an essential role in insulin secretion [34].

Other studies have found an association between vitamin D and $\operatorname{HbA} 1 \mathrm{C}[13,35,36]$. However, there is no direct relationship between the vitamin $\mathrm{D}$ metabolism and $\mathrm{HbA} 1 \mathrm{C}$ since high levels of $\mathrm{HbA} 1 \mathrm{c}$ may be due to changes in insulin secretion, which is compromised by vitamin $D$ deficiency. Moreover, HbA1c is also elevated when there are changes in insulin-stimulated glucose uptake into muscle and adipose tissue.

The anthropometric parameters were higher in the Vitamin D Deficiency group than in the Vitamin D Sufficiency group. The association between vitamin $D$ and fat percentage can be explained by vitamin $D$ storage in the adipose tissue, and there is an inverse correlation between serum 25OHD and total adipose tissue and its fractions [37,38]. High waist circumference was observed in the Vitamin D Deficiency group, which can be attributed to the active role that vitamin $D$ plays in the adipose tissue by modulating the inflammatory response and reducing adipogenesis and adipocyte secretion [39]. A meta-analysis including groups of different ages found an association between vitamin $D$ deficiency and obesity, regardless of age, latitude, cutoff point for vitamin deficiency, and the Human Development Index of the region where the study was carried out [40]. 
The lean body mass values found in the Vitamin D Deficiency group are different from those reported in other studies, which showed a positive correlation between vitamin $\mathrm{D}$ and lean mass $[41,42]$. The high percentage of lean mass in the Vitamin D Deficiency group may be due to factors other than engagement in physical activities. The participants' occupation may explain this finding since many of them carry out moderate work activities. In the literature, there is strong evidence of the role of vitamin $D$ in the relationship between muscle and bone tissues. Mechanistic studies demonstrate a range of genomic effects of vitamin $D$ on cell differentiation, bone mineralization, and muscle fiber size [43].

The number of altered metabolic syndrome components was larger in Vitamin D Deficiency group. However, such association is still controversial since some studies did not find a relationship between metabolic syndrome and vitamin $D$ deficiency $[15,16]$. On the other hand, other studies have shown an inverse correlation between vitamin $D$ and metabolic syndrome components $[14,44,45]$. Godala et al. [44] found lower vitamin D concentrations in postmenopausal women with metabolic syndrome than in postmenopausal women without metabolic syndrome [46]. Lower vitamin D concentrations were also observed in subjects with metabolic syndrome than in individuals without metabolic syndrome in a large representative sample of the United States population [45]. Divergence between results involving vitamin $D$ and metabolic syndrome may be due to differences in the criteria for classification of metabolic syndrome and differences between races, BMI, and glucose levels, among others.

It is known that low sun exposure is one of the reasons for vitamin $D$ deficiency/insufficiency [46]. The results obtained in the present study corroborate this assertion since it was found that the individuals who were deficient in vitamin $D$ were those who got less frequent sun exposure.
It is important to mention that the participants of this study were still working and many worked indoors, and therefore, they were less exposed to sunlight.

The high prevalence of vitamin $D$ deficiency/insufficiency has been a common finding in studies carried out in several parts of the world [2], including Brazil, despite its geographical location and abundant solar irradiation [46]. In the present study, it was found that $64.2 \%$ of the individuals had deficiency/insufficiency of vitamin D, a similar result to that of other studies carried out in the state of São Paulo. Peters et al. [47] found prevalence of vitamin D insufficiency in $60.0 \%$ of the adolescents studied. Among older adults, the rate of vitamin $D$ deficiency/insufficiency reached 57.3\% [48]. Another study evaluating Brazilian adolescents from a different region, the southern part of the country, found $54.3 \%$ of vitamin D insufficiency and $36.3 \%$ of vitamin D deficiency [49].

Many polymorphisms of the VDR gene have been identified (Fokl, Bsml, Apal, and Taql). Some of these polymorphisms have been associated with type 2 diabetes and insulin secretion [50,51]. A relationship between the polymorphisms of the VDR gene and the metabolic syndrome components such as insulin secretion, insulin resistance, and low HDL-c has also been reported [52], which may be another reason for the high prevalence of metabolic alterations associated with vitamin D deficiency.

In the present study, reference values were used to determine the vitamin D status, according to Holick et al. [17]. However, it is worth highlighting that these values vary between authors, and there is no consensus in the literature on the most appropriate reference range.

The present study showed some limitations such as the reduced number of subjects, the use of bioelectrical impedance to assess body composition, and the use of HOMAIR index to evaluate insulin resistance, which 
are not considered gold standard methods. However, despite these limitations, the results obtained are consistent with those of other studies.

Finally, it was observed that vitamin D deficiency leads to more metabolic alterations such as elevated triglycerides, VLDL-c, insulin, glucose, HbA1c, PTH, and HOMA-IR. Furthermore, this study points out that vitamin $\mathrm{D}$ deficiency is also associated with high body fat percentage, waist circumference, and BMI, and that these changes may contribute to the onset of diseases such as diabetes Mellitus and metabolic syndrome.

\section{ACKNOWLEDGEMENTS}

The authors are grateful for the financial support of the Fundo de Apoio ao Ensino, à Pesquisa e Extensão to Dr. Dora Maria Grassi Kassisse for assistance in statistical analysis of the data, and to all volunteers who participated in this study.

\section{CONTRIBUTIONS}

LM ROCHA contributed to the conception and design of this study, to data collection, interpretation, and analysis, and manuscript writing and final revision. DCS BALDAN and AL SOUZA contributed to data collection. EA CHAIM, EJ PAVIN, and SM ALEGRE contributed to the conception and design of the present study.

\section{RE FERE N CES}

1. Holick MF. Vitamin D: A D-Lightful health perspective. Nutr Rev. 2008;66(10Suppl.2): S182-94. https://doi.org/10.1111/j.1753-4887.2008.00 104.x

2. Mithal A, Wahl DA, Bonjour JP, Burckhardt P, Dawson-Hughes B, Eisman JA, et al. IOF Committee of Scientific Advisors (CSA) Nutrition Working Group. Global vitamin D status and determinants of hypovitaminosis D. Osteoporos Int. 2009;20(11):1807-20. https://doi. org/10.1007/s00198-009-0954-6

3. Webb AR, Kline L, Holick MF. Influence of season and latitude on the cutaneous synthesis of vitamin D3: Exposure to winter sunlight in Boston and Edmonton will not promote vitamin D3 synthesis in human skin. J Clin Endocrinol Metab. 1988;67(2):373-8. https://doi.org/10.1210/jcem67-2-373

4. Hickey L, Gordon CM. Vitamin D deficiency: New perspectives on an old disease. Curr Apin Endocrinol Diabetes. 2004;11(1):18-25. https:// doi.org/10.1097/00060793-200402000-00006

5. Didier FBCW, Brum LFS, Aerts DRGC. Hábitos de exposição ao sol e uso de fotoproteção entre estudantes universitários de Teresina, Piauí. Epidemiol Serv Saúde. 2014;23(3):487-96. https:// doi.org/10.5123/S1679-49742014000300011

6. Ramagopalan SV, Heger A, Berlanga AJ, Maugeri NJ, Lincoln MR, Burrell $A$, et al. A chlP-seq defined genome- wide map of vitamin $D$ receptor binding: Associations with disease and evolution. Genome Res. 2010;20(10):1352-60. https://doi. org/10.1101/gr.107920.110

7. Goldner WS, Stoner JA, Thompson J, Taylor K, Larson L, Erickson J, et al. Prevalence of vitamina $D$ insufficiency and deficiency in morbidly obese patients: A comparison with non-obese controls. Obes Surg. 2008;18(2):145-50. https://doi.org/10. 1007/s11695-007-9315-8

8. Rodriguez-Rodriguez E, Navia B, Lopez-Sobaler AM, Ortega RM. Vitamina $D$ in overweight/ obese women and its relationship with dietetic and anthropometric variables. Obesity. 2009;17(4):778-82. https://doi.org/10.1038/oby. 2008.649

9. Tsur A, Feldman BS, Feldhammer I, Hoshen MB, Leibowitz G, Balicer RD. Decreased serum concentrations of 25-hydroxycholecalciferol are associated with increased risk of progression to impaired fasting glucose and diabetes. Diabetes Care. 2013;36(5):1361-7. https://doi. org/10.2337/dc12-1050

10. Lim S, Kim MJ, Choi SH, Shin CS, Park KS, Jang $\mathrm{HC}$, et al. Association of vitamin D deficiency with incidence of type 2 diabetes in high-risk Asian subjects. Am J Clin Nutr. 2013;97(3):524-30. https://doi.org/10.3945/ajcn.112.048496

11. Ceglia L, Nelson J, Ware J, Alysandratos $K D$, Bray GA, Garganta C, et al. Association between body weight and composition and plasma 25-hydroxyvitamin $D$ level in the Diabetes Prevention Program. Eur J Nutr. 2017;56(1):161-70. https://doi.org/10.1007/s00394-015-1066-z

12. Han SS, Kim M, Lee SM, Lee JP, Kim S, Joo KW, et al. Association between body fat and vitamin D status in Korean adults. Asia Pac J Clin Nutr. 2014;23(1):65-75. https://doi.org/10.6133/apjcn. 2014.23.1.10 
13. McGill A, Stewart JM, Lithander FE, Strik CM, Poppitt SD. Relationships of low serum vitamin D3 with anthropometry and markers of the metabolic syndrome and diabetes in overweight and obesity. Nutr J. 2008;7(28):4. https://doi.org/10. 1186/1475-2891-7-4

14. Yoon H, Kim GS, Kim SG, Moon AE. The relationship between metabolic syndrome and increase of metabolic syndrome score and serum vitamin D levels in Korean adults: 2012 Korean National Health and Nutrition Examination Survey. J Clin Biochem Nutr. 2015;57(1):82-7. https://doi. org/10.3164/jcbn. 15-31

15. Khader YS, Batieha A, Jaddou H, Batieha Z, El-Khateeb M, Ajlouni K. Relationship between 25-hydroxyvitamin D and metabolic syndrome among Jordanian adults. Nutr Res Pract. 2011;5:132-9. https://doi.org/10.4162/nrp.2011. 5.2.132

16. Hjelmesaeth J, Hofsø D, Aasheim ET, Jenssen T, Moan J, Hager $\mathrm{H}$, et al. Parathyroid hormone, but not vitamin $\mathrm{D}$, is associated with the metabolic syndrome in morbidly obese women and men: A cross-sectional study. Cardiovasc Diabetol. 2009;8(3):7. https://doi.org/10.1186/1475-28 40-8-7

17. Holick MF, Binkley NC, Bischoff-Ferrari HA, Gordon CM, Hanley DA, Heaney RP, et al. Evaluation, treatment, and prevention of vitamin D deficiency: An endocrine society clinical practice guideline. J Clin Endocrinol Metab. 2011;96(7):1911-30. https://doi.org/10.1210/jc.2011-0385

18. Sociedade Brasileira de Cardiologia, Sociedade Brasileira de Hipertensão, Sociedade Brasileira de Nefrologia. VI Diretrizes Brasileiras de Hipertensão. Arq Bras Cardiol. 2010;95(1Supl.1):1-51.

19. World Health Organization. Obesity: Preventing and managing the global epidemic. Genebra: WHO; 1997. https://doi.org/10.1017/S002193200 3245508

20. Lohman TG, Roche AF, Martorell R. Anthropometric standardization reference manual. Champaign: Human Kinetics Pub; 1988.

21. Van Der Kooy KVD, Seidell JC. Techniques for the measurement of visceral fat: A practical guide. Int J Obes Relat Metab Disord. 1993;17(4):187-96.

22. Ford ES, Kohl III HW, Mokdad AH, Ajani UA. Sedentary behavior, physical activity, and the metabolic syndrome among U.S. adults. Obes Res. 2005;13(3):608-14. https://doi.org/10.1038/ oby. 2005.65

23. Hanwell HE, Vieth $R$, Cole DE, Scillitani A, Modoni $S$, Frusciante $V$, et al. Sun exposure questionnaire predicts circulating 25-hydroxyvitamin D concentrations in Caucasian hospital workers in southern Italy.
Steroid Biochem Mol Biol. 2010;121(1-2):334-7. https://doi.org/10.1016/j.jsbmb.2010.03.023

24. Matthews DR, Hosker JP, Rudenski AS, Naylor BA, Treacher DF, Turner RC. Homeostasis model assessment: Insulin resistance and B-cell function from fasting plasma glucose and insulin concentrations in man. Diabetologia. 1985;28(7):412-9. https://doi.org/10.1007/BF002 80883

25. American Diabetes Association. Diagnosis and classification of diabetes Mellitus. Diabetes Care. 2013;36(Suppl.1):S67-74. https://doi.org/10.2337/ dc10-S062

26. Geloneze B, Vasques AC, Stabe CF, Pareja JC, Rosado LE, Queiroz EC, et al. HOMA1-IR and HOMA2-IR indexes in identifying insulin resistance and metabolic syndrome: Brazilian Metabolic Syndrome Study (BRAMS). Arq Bras Endocrinol Metabol. 2009;53:281-7. https://doi. org/10.1590/S0004-27302009000200020

27. Alberti KG, Zimmet P, Shaw J. IDF Epidemiology Task Force Consensus Group: The metabolic syndrome: A new worldwide definition. Lancet. 2005;366(9491):1059-62. https://doi.org/10.10 16/S0140-6736(05)67402-8

28. Bachali S, Dasu K, Ramalingam K, Naidu JN. Vitamin D Deficiency and Insulin Resistance in Normal and Type 2 Diabetes Subjects. Ind J Clin Biochem. 2013;28(1):74-8. https://doi. org/10.1007/s12291-012-0239-2

29. Bilge U, Ünalacak M, Ünlüoğlu İ, İpek M, Çeler Ö, Akalin A. Relationship between 1,25-dihydroxy Vitamin D levels and homeostatic model assessment insulin resistance values in obese subjects. Niger J Clin Pract. 2015;18(3):377-80. https://doi.org/10.4103/1119-3077.151757

30. Dutta D, Maisnam I, Shrivastava A, Sinha A, Ghosh S, Mukhopadhyay $P$, et al. Serum vitamin-D predicts insulin resistance in individuals with prediabetes. Indian J Med Res. 2013;138(6):853-60.

31. Ishida H, Norman AW. Demonstration of a high affinity receptor for 1,25-dihydroxyvitamin D3 in rat pancreas. Moll Cell Endocrinol. 1988;60(2-3):109-17. http://doi.org/10.1016/0303-7207(88)90169-4

32. Bland R, Markovic D, Hills CE, Hughes SV, Chan SL, Squires PE, et al. Expression of 25-hydroxyvitamin D3-1alpha-hydroxylase in pancreatic islets. J Steroid Biochem Mol Biol. 2004;89-90(1-5):121-5. https://doi.org/10.1016/j.jsbmb.2004.03.115

33. Maestro B, Campion J, Davila N, Calle C. Stimulation by 1,25-dihydroxyvitamin D3 of insulin receptor expression and insulin responsiveness for glucose transport in U-937 human promonocytic cells. Endocr J. 2000;47:383-91. https://doi.org/10. 1507/endocrj.47.383 
34. Maestro B, Molero S, Bajo S, Dávila N, Calle C. Transcriptional activation of the human insulin receptor gene by 1,25-dihydroxyvitamin $D(3)$. Cell Biochem Funct. 2002;20(3):227-32. https://doi. org/10.1002/cbf.951

35. Kositsawat J, Freeman VL, Gerber BS, Geraci S. Association of A1C levels with vitamin D status in U.S. adults: Data from the National Health and Nutrition Examination Survey. Diabetes Care. 2010;33(6):1236-8. https://doi.org/10.2337/dc0 9-2150

36. Manickam B, Neagu V, Kukreja S, Barengolts E. Relationship between glycated hemoglobin and circulating 25-hydroxyvitamin D concentration in African American and Caucasian American men. Endocr Pract. 2013;19(1):73-80. https://doi. org/10.4158/EP12168.OR

37. Kremer R, Campbell PP, Reinhardt T, Gilsanz V. Vitamin D status and its relationship to body fat, final height, and peak bone mass in young women. J Clin Endocrinol Metab. 2009;94(1):6773. https://doi.org/10.1210/jc.2008-1575

38. Caron-Jobin M, Morisset A, Tremblay A, Huot C, Légaré $D$, Tchernof $A$. Elevated serum 25(OH)D concentrations, vitamin D, and calcium intakes are associated with reduced adipocyte size in women. Obesity. 2011;19(7):1335-41. https://doi. org/10.1038/oby.2011.90

39. Shivaprakash JM, Hyppönen E, Saarnio J, Järvelin M, Herzig K. Vitamin D and adipose tissue: More than storage. Front Physiol. 2014;5(24):228. https://doi.org/10.3389/fphys.2014.00228

40. Pereira-Santos M, Costa PRF, Assis AMO, Santos CAST, Santos DB. Obesity and vitamin D deficiency: A systematic review and meta-analysis. Obes Rev. 2015;16(4):341-9. https://doi.org/10.1111/obr.12 239

41. Shantavasinkul PC, Phanachet P, Puchaiwattananon $\mathrm{O}$ Chailurkit LO, Lepananon $\mathrm{T}$, Chanprasertyotin $\mathrm{S}$, et al. Vitamin D status is a determinant of skeletal muscle mass in obesity according to body fat percentage. Nutrition. 2015;31(6):801-6. https://doi.org/10.1016/j.nut. 2014.11.011

42. Fornari R, Francomano D, Greco EA, Marocco C, Lubrano C, Wannenes F, et al. Lean mass in obese adult subjects correlates with higher levels of vitamin D, insulin sensitivity and lower inflammation. J Endocrinol Invest. 2015;38(3):367-72. https://doi.org/10.1007/s40618-014-0189-z

43. Gunton JE, Girgis MC, Baldock AP, Lips P. Bone muscle interactions and vitamin D. Bone. 2015;80:89-94. https://doi.org/10.1016/j.bone.20 15.02.029

44. Godala M, Materek-Kuśmierkiewicz I, Moczulski D, Gaszyńska E, Szatko F, Tokarski S, et al.
Assessment of $25(\mathrm{OH}) \mathrm{D}$ vitamin concentration in plasma of residents of Lodz with metabolic syndrome in pre- and postmenopausal period. Menopause Rev. 2014;13(5):293-7. https://doi. org/10.5114/pm.2014.46473

45. Ford ES, Ajani UA, McGuire LC, Liu S. Concentration of serum vitamin $D$ and the metabolic syndrome among U.S. adults. Diabetes Care. 2005;28(5):1228-30. https://doi.org/10.2337/diacare.28.5.1228

46. Martini LA, Verly E Jr, Marchioni DM, Fisberg RM. Prevalence and correlates of calcium and vitamin D status adequacy in adolescents, adults, and elderly from the Health Survey - São Paulo. Nutrition. 2013;29(6):845-50. https://doi.org/10.1016/j.nut. 2012.12.009

47. Peters BSE, Santos LC, Fisberg M, Wood RJ, Martini LA. Prevalence of vitamin D insufficiency in Brazilian adolescentes. Ann Nutr Metab. 2009;54(1):15-21. https://doi.org/10.1159/000199454

48. Saraiva GL, Lazaretti-Castro M, Cendoroglo MS, Araújo LM, Vieira JG, Kunii I, et al. Influence of ultraviolet radiation on the production of 25 hydroxyvitamin $\mathrm{D}$ in the elderly population in the city of São Paulo (2334'S), Brazil. Osteop Int. 2005;16(12):1649-54. https://doi.org/10.1007/s00 198-005-1895-3

49. Santos BR, Mascarenhas LPG, Satler F, Boguszewski MCS, Spritzer PM. Vitamin D deficiency in girls from South Brazil: A cross-sectional study on prevalence and association with vitamin D receptor gene variants. Pediatrics. 2012;12:62. https://doi.org/10.1186/1471-2431-12-62

50. Ortlepp JR, Lauscher J, Hoffmann R, Hanrath P, Joost $H G$. The vitamin $D$ receptor gene variant is associated with the prevalence of type 2 diabetes Mellitus and coronary artery disease. Diabet Med. 2001;18(10):842-5. https://doi.org/10.1046/j.14 64-5491.2001.00585.x

51. Ogunkolade BW, Boucher BJ, Prahl JM, Bustin SA, Burrin JM, Noonan K, et al. Vitamin D receptor (VDR) mRNA and VDR protein levels in relation to vitamin D status, insulin secretory capacity, and VDR genotype in Bangladeshi Asians. Diabetes. 2002;51(7):2294-300. https://doi.org/10.2337/ diabetes.51.7.2294

52. Schuch NJ, Garcia VC, Vívolo SRGF, Martini LA. Relationship between Vitamin D Receptor gene polymorphisms and the components of metabolic syndrome. Nutr J. 2013;12:96. https://doi.org/10. 1186/1475-2891-12-96

Received: October 24, 2016 Final version: January 2, 2017 Approved: March 29, 2017 